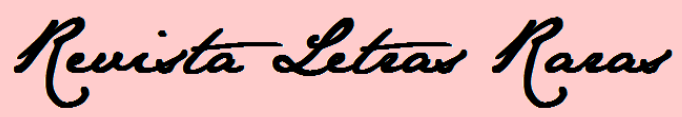

ISSN: 2317-2347 - v.6, n.1 (2017)

\title{
Os processos formativos do professor de Língua Inglesa no curso de Letras da UTFPR e no Programa Idiomas sem Fronteiras: a questão da internacionalização do Ensino Superior/ The pre-service English teacher education in the undergraduate Modern Languages course of Universidade Tecnológica Federal do Paraná and in the English without Borders Program: the internationalization of higher education issue
}

\author{
Mirelle Mussi Giri* \\ Claudia Beatriz Monte Jorge Martins ${ }^{* *}$
}

\begin{abstract}
RESUMO
O presente artigo objetiva analisar a questão dos processos formativos do professor de língua inglesa no curso de Licenciatura em Letras Português/Inglês da Universidade Tecnológica Federal do Paraná (UTFPR), câmpus Curitiba, e no Programa Federal Idiomas sem Fronteiras (IsF) com relação à internacionalização do ensino superior, entendida como uma estratégia de adaptação aos novos desafios e demandas impostos pela globalização. A pesquisa, de natureza descritiva, adotou dois procedimentos para a coleta de dados: pesquisa bibliográfica e documental, e levantamento quantitativo por meio de questionário como instrumento de coleta de dados. O questionário foi aplicado aos licenciandos do curso de Licenciatura em Letras Português/Inglês da UTFPR regularmente matriculados nas disciplinas de Estágio Curricular Obrigatório em Língua Inglesa I, II e III no segundo semestre do ano de 2016. Seu objetivo foi verificar como a formação docente do curso efetivamente se relaciona com o processo de internacionalização do ensino superior na prática. Os resultados mostram que os processos formativos oportunizados nas disciplinas não se articulam com a internacionalização do ensino superior e que o Programa IsF poderia complementar a formação dos professores bolsistas acadêmicos do curso de Licenciatura em Letras Português/Inglês da UTFPR.
\end{abstract}

PALAVRAS-CHAVE: IsF. Internacionalização. Professor. Letras. Inglês.

\section{ABSTRACT}

The present article aims to analyze the issue of the pre-service English teacher education in the undergraduate Modern Languages course of Universidade Tecnológica Federal do Paraná (UTFPR), campus Curitiba, and in the Languages without Borders Program $(L w B)$ regarding the internationalization of higher education, understood as a strategy to adapt to the new challenges and demands imposed by globalization. The research, of descriptive nature, adopted two procedures for the data collection: bibliographic and documentary research, and quantitative survey through the use of a questionnaire as an instrument for data collection. The questionnaire was applied to undergraduate students in the Modern Languages course at UTFPR regularly enrolled in the disciplines English Teaching Practicum I, II and III in the second semester of 2016. Its objective was to verify how the teacher education in the course effectively relates to the process of internationalization of higher education in practice. The results show that the teacher education developed in the subjects are not articulated with the internationalization of higher education and that the LwB Program could complement the training of its scholar teachers who are undergraduate students of the Mordern Languages course at UTFPR.

KEYWORDS: LwB. Internationalization. Teacher. Languages. English.

\footnotetext{
* Licenciada em Letras Português/Inglês pela Universidade Tecnológica Federal do Paraná, campus Curitiba, e em Direito pela Pontifícia Universidade Católica do Paraná. Endereço eletrônico: mirellemussi@ hotmail.com

** Licenciada em Letras pela Universidade Federal do Paraná, Mestre em Engenharia de Produção pela Universidade Federal de Santa Catarina, Doutora em Tecnologia pela Universidade Tecnológica Federal do Paraná e Docente do Departamento Acadêmico de Línguas Estrangeiras Modernas da Universidade Tecnológica Federal do Paraná, campus Curitiba. Endereço eletrônico: claudiab@utfpr.edu.br
} 


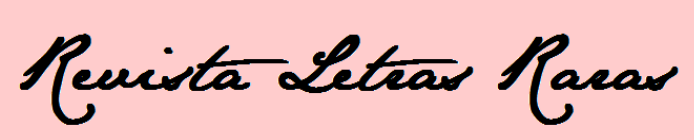

ISSN: 2317-2347 - v.6, n.1 (2017)

\section{Introdução}

As relações sociais na contemporaneidade são fortemente marcadas por um contexto socioeconômico de conectividade e competitividade crescentes em virtude de um fenômeno conhecido por globalização (LIMA FILHO, 2004; WHITE, 1998).

As sociedades globalizadas vivenciam, assim, um crescente processo de diluição das fronteiras que as aproximam e conectam em níveis sem precedentes, impactando a economia, a política, o modo de vida e a cultura das pessoas (ARCHANJO, 2015; BATISTA, 2009; LIMA FILHO, 2004; WHITE, 1998; MAGNOLI, 1997).

Registram-se, desse modo, profundas mudanças em todos os aspectos da vida contemporânea, fazendo com que indivíduos e sociedades se tornem mais críticos, seletivos e exigentes diante da imensa disponibilidade e variedade de informações, tecnologias, conhecimento, produtos e serviços (ARCHANJO, 2015; LOPES, 2003; WHITE, 1998).

A globalização demanda, portanto, que indivíduos e sociedades desenvolvam estratégias e soluções de modo a assegurar sua relevância e distinção em um contexto global cada vez mais integrado (WHITE, 1998).

As instituições de ensino superior (IES), por contribuírem para o avanço dos conhecimentos e desenvolvimento, tornam-se indispensáveis para o processo de adaptação das sociedades às mudanças provocadas pela globalização (TEODORO, 2011; SOUZA, 2008; KNIGHT, 2005; DIAS SOBRINHO; 2005; WHITE, 1998).

Dentre as estratégias adotadas pelas IES para se adequarem às novas demandas, destaca-se o processo de internacionalização, esforço sistemático materializado por meio de políticas, programas, ações, dentre outras iniciativas, empreendidas por governos, sistemas acadêmicos e instituições para estimular a troca colaborativa entre os países (LAUS, 2012; ALTBACH, 2010; KNIGHT, 2008; MARRARA, 2007; WENDE, 1997).

A UTFPR, contexto base desta pesquisa, é uma instituição que tenta se inserir na complexidade moderna pela busca de "respostas para os desafios do novo conhecimento, da tecnologia e da inovação, da educação, da pesquisa e da capacitação tecnológica" (UTFPR, 2007, p. 9). Para tanto, estabeleceu a internacionalização como uma política institucional e adotou inúmeras iniciativas, dentre elas a participação nos Programas Ciência sem Fronteiras (CsF) e Idiomas sem Fronteiras (IsF).

O CsF consistiu de uma política pública de abrangência nacional voltada para a consolidação, expansão e internacionalização da ciência e tecnologia brasileiras por meio de 


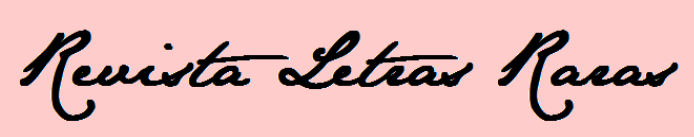

ISSN: 2317-2347 - v.6, n.1 (2017)

programas de intercâmbio e mobilidade internacional. Seu objetivo foi viabilizar a construção de um país mais academicamente capaz, cientificamente qualificado e competitivo. Consolidou, também, a ideia da internacionalização do ensino superior como resposta aos desafios impostos pela globalização (CSF, 2016; STALLAVIERI, 2015; OLIVEIRA, 2015; BRASIL, 2011).

Entretanto, foi constatado que seus participantes tinham baixa proficiência em línguas estrangeiras, o que motivou o governo brasileiro a traçar ações complementares no âmbito das políticas linguísticas, resultando no lançamento do Programa IsF (GIMENEZ; PASSONI, 2016; BRASIL, 2012).

Em sua fase inicial, o IsF objetivou "propiciar a formação e capacitação de alunos de graduação das instituições de ensino superior para os exames linguísticos exigidos para o ingresso nas universidades anglófonas" (BRASIL, 2012, p. 28) e a contribuir para o processo de internacionalização das IES e dos centros de pesquisa brasileiros (LANGUAGES..., 2016; ARCHANJO, 2015; BRASIL, 2012).

Percebeu-se, também, que o IsF tornou-se um ambiente propício para o desenvolvimento do professor de língua inglesa por priorizar a participação de licenciandos em Letras como professores bolsistas (RAMOS et al.; 2016; BRASIL, 2016; SARMENTO; KIRSCH, 2015).

Posteriormente, o IsF foi reformulado de modo a incorporar outras línguas e passou a se chamar Idiomas sem Fronteiras, preservando, no entanto, a mesma sigla (BRASIL, 2014). Seu objetivo foi "ampliar a perspectiva dos estudantes brasileiros em relação à formação em línguas estrangeiras, expandindo o multilingualismo" (BRASIL, 2016, p. 11), fortalecendo a convicção de que é fundamental ofertar outras línguas para promover uma ampla internacionalização das IES brasileiras (OTTO, 2016).

O Programa estabeleceu também como objetivo o fortalecimento das licenciaturas e da formação de professores de idiomas nas IES credenciadas, bem como dos professores de idiomas da educação básica (GIMENEZ; PASSONI, 2016; BRASIL, 2014).

Não resta dúvida, portanto, que o IsF reverberou para o campo da formação de professores, dimensão que foi introduzida como discurso oficial, passando a alicerçá-lo (BRASIL, 2016; LANGUAGES..., 2016; SARMENTO; KIRSCH, 2015).

Mais recentemente, a Portaria $n^{\circ} 30 / 2016$ consolidou essa perspectiva ao estabelecer que o IsF deve contribuir para a "formação inicial dos estudantes de licenciatura em língua 


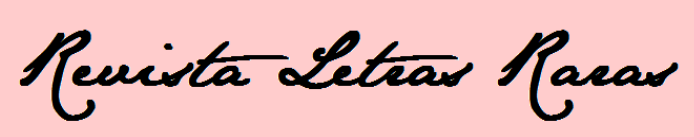

ISSN: 2317-2347 - v.6, n.1 (2017)

estrangeira e a formação continuada de professores de língua estrangeira, para fins específicos de internacionalização nas IES e nas escolas brasileiras" (BRASIL, 2016, p. 18).

A partir desse contexto, e também em virtude da escassez de trabalhos que proporcionem uma visão mais estratégica dos processos formativos do professor de língua inglesa sob a perspectiva da internacionalização, este artigo objetiva analisar os processos formativos do professor de língua inglesa no curso de Licenciatura em Letras Português/Inglês da UTFPR, câmpus Curitiba, e no Programa IsF com relação à internacionalização do ensino superior, entendida como uma estratégia de adaptação aos novos desafios e demandas impostos pela globalização.

Para tanto, propõe: descrever, brevemente, a partir de documentos oficiais, a formação do professor de línguas estrangeiras no Brasil e no Paraná, e a formação na Licenciatura em Letras Português/Inglês da UTFPR e no Programa IsF; verificar como os processos formativos do professor de língua inglesa nos Estágios Curriculares Obrigatórios em Língua Inglesa I, II e III do referido curso se relacionam, na prática, com a internacionalização do ensino superior sob a ótica dos licenciandos envolvidos; e verificar se o processo formativo oportunizado aos professores bolsistas do Programa IsF, acadêmicos do curso de Letras da UTFPR, possibilita reforçar ou complementar os processos formativos desenvolvidos nos supramencionados Estágios com relação à internacionalização do ensino superior.

\section{A formação do professor de Língua Estrangeira no Brasil e no Paraná}

Diante de uma conjuntura em que a comunicação adquire um papel cada vez mais centralizado nas sociedades globalizadas em virtude das novas dinâmicas de integração mundial, é inegável que o professor conquista, também, uma posição mais estratégica por desempenhar um papel decisivo na preparação das pessoas para a vida. Isso repercute, similarmente, nos processos de formação docente, que precisam se adequar a contextos dinâmicos e desafiadores (ENGELMANN, 2012; VOLPI, 2008; LOPES, 2003).

O processo formativo do professor de línguas estrangeiras no Brasil pauta-se, primeiramente, a partir do disposto na Lei de Diretrizes e Bases da Educação Brasileira (LDB), que entende que a finalidade básica da educação é desenvolver plenamente o educando, preparando-o para o exercício da cidadania (BRASIL, 1996). 


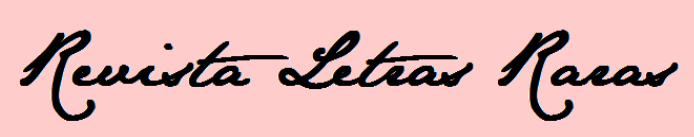

ISSN: 2317-2347 - v.6, n.1 (2017)

Esse preceito levou à publicação de diversos documentos que guiam a formação do professor da educação básica (ZAMBONI, 2013). Dentre eles, três se destacam pela relevância para a presente pesquisa.

O primeiro, Parecer CNE $n^{\circ} 776 / 1997$, entende que a LDB assegura maior flexibilidade às IES na organização de cursos e destaca a necessidade da oferta de uma formação básica sólida, de modo que o profissional possa "enfrentar os desafios das rápidas transformações da sociedade, do mercado de trabalho e das condições de exercício profissional" (BRASIL, 1997, p. 2).

O segundo, Parecer CNE/CES no 492/2001, estabelece que a universidade deve atender às necessidades educativas e tecnológicas da sociedade formando um professor que domine o uso da língua que seja objeto de seus estudos, reflita teoricamente sobre a linguagem, faça uso de novas tecnologias e compreenda sua formação como um processo contínuo, autônomo e permanente (BRASIL, 2001).

$\mathrm{O}$ terceiro, Resolução $\mathrm{CNE} / \mathrm{CP} \mathrm{n}^{\circ} 1 / 2002$, confere autonomia às instituições na elaboração de currículos próprios e inovadores que desenvolvam diferentes competências necessárias à atuação profissional, desde que observados os princípios, fundamentos e procedimentos norteadores estabelecidos nos documentos relativos à formação do professor de educação básica (BRASIL, 2002).

Além desses documentos, faz-se necessário trazer à luz outros dois que norteiam a prática do professor de línguas estrangeiras e a elaboração dos projetos pedagógicos e dos currículos dos cursos de licenciatura em Letras (VOLPI, 2008).

Os Parâmetros Curriculares Nacionais para a Educação Básica (PCN) estabelecem os referenciais nacionais comuns ao processo educativo em todo o Brasil e as informações necessárias ao desempenho profissional docente (MENDES, 2011; BRASIL, 1998).

O papel da educação, segundo o documento, aponta para a construção de uma escola que viabilize o acesso aos conhecimentos necessários ao exercício da cidadania, o que só pode ser alcançado se a aprendizagem estiver revestida por uma função social. No processo de ensino-aprendizagem de línguas, isso está condicionado ao desenvolvimento de ao menos uma habilidade, a de leitura, por ser entendida como a mais relevante para o contexto social dos educandos (BRASIL, 1998).

As Orientações Curriculares para o Ensino Médio (OCEM), por sua vez, é um documento de apoio à reflexão teórico-pedagógica do professor. Sua proposta aponta para um trabalho que, além de ensinar um idioma estrangeiro, deve contribuir para uma formação que 


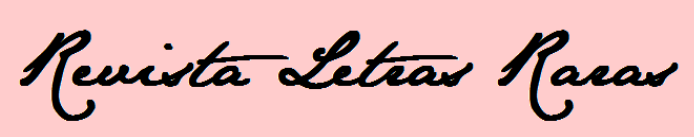

ISSN: 2317-2347 - v.6, n.1 (2017)

desenvolva a compreensão sobre que lugar o aluno ocupa na sociedade, o que vai muito além da instrumentação linguística (BRASIL, 2006).

O documento silencia em relação à habilidade de compreensão oral, focalizando apenas o desenvolvimento da leitura, escrita e comunicação oral. Orienta, também, que as aulas devem ser planejadas a partir de temáticas que favoreçam a formação crítica e cidadã dos educandos (BRASIL, 2006).

Complementarmente, destacam-se as Diretrizes Curriculares da Educação Básica no Paraná, que indicam um trabalho cujos conteúdos disciplinares devem contribuir para a formação crítica dos educandos com vistas à transformação da realidade social, econômica e política (PARANÁ, 2008).

O documento se embasa na pedagogia crítica, abordagem que defende a superação de um ensino de línguas baseado na abordagem comunicativa e privilegia aquele em que o aluno reconheça e compreenda a diversidade linguística e cultural, envolvendo-se discursivamente e percebendo as possibilidades de construção de significados do mundo em que vive (PARANÁ, 2008).

O ensino de língua proposto é, pois, aquele que supera fins utilitaristas, pragmáticos ou instrumentais. A aula, por sua vez, deve ser um espaço que permita o acesso a discursos que circulam globalmente, que construa discursos alternativos e que promova a luta contra a hegemonia e a favor da diversidade. E, por fim, os encaminhamentos metodológicos, voltados para a educação básica, devem focar a leitura, escrita e produção oral, com especial atenção na leitura e no trabalho com diferentes gêneros textuais (PARANÁ, 2008).

\section{A formação do professor de Língua Inglesa na UTFPR}

Com o intuito de se delinear como se dá o processo formativo do professor de língua inglesa no curso de Letras Português/Inglês da UTFPR, será analisado, brevemente, seu Projeto Pedagógico (UTFPR, 2011).

No que tange à justificativa para a oferta da licenciatura pela instituição, entende-se que a língua inglesa faz parte do conjunto de conhecimentos essenciais que possibilita ao aluno aproximar-se de outras culturas, viabilizando sua integração ao mundo globalizado de forma mais sólida e abrangente. 


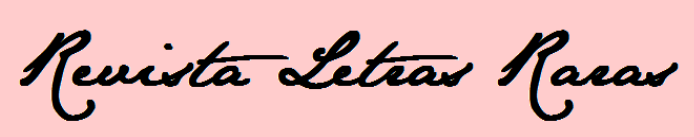

ISSN: 2317-2347 - v.6, n.1 (2017)

O documento ressalta, ainda, que é em virtude da importância e da necessidade de seu conhecimento na atualidade que se faz necessário formar professores de língua inglesa para atuarem especialmente na educação básica da rede pública, esfera em que a maioria dos alunos tem o primeiro contato com a língua e onde há maior defasagem de profissionais.

Para transformar esse quadro, as licenciaturas devem se voltar para uma formação qualificada e engajada na transformação cultural da realidade, em consonância com o que estabelece a LDB.

Tendo em vista esse objetivo, o documento define as habilidades e competências profissionais necessárias que devem ser desenvolvidas durante a graduação. Para tanto, estabelece que a matriz curricular do curso deve ser organizada em eixos articulados de forma que os conhecimentos básicos possam se entrelaçar.

Para a presente pesquisa, importa analisar, particularmente, o espaço curricular do Estágio. Tratam-se de disciplinas que visam proporcionar ao acadêmico as competências e habilidades necessárias para a sua formação por meio de estudos e análises do processo de ensino-aprendizagem da língua inglesa, pelo contato com a realidade educacional das escolas que ofertam os ensinos fundamental e médio, pelo desenvolvimento de alternativas metodológicas, e pela regência assistida em turmas desses níveis de ensino.

Ofertado no sexto período e com enfoque no ensino fundamental, o Estágio Curricular Obrigatório em Língua Inglesa I prevê em sua ementa: estudos e análises críticoreflexivas dos PCN, OCEM, Diretrizes Estaduais, LDB e Projeto Político Pedagógico da comunidade escolar onde os alunos estiverem inseridos; elaboração de planos de ensino e de aula; análise crítico-reflexiva sobre o processo ensino-aprendizagem e suas implicações no currículo dos ensinos fundamental e médio; crenças sobre o ensino/aprendizagem de línguas estrangeiras modernas; observação e análise da realidade educacional da comunidade.

O Estágio II, por sua vez, ofertado no sétimo período com enfoque no ensino médio, prevê: retomada dos estudos e análises crítico-reflexivas dos documentos oficiais estudados no primeiro estágio sobre o processo de ensino-aprendizagem da língua inglesa nos ensinos fundamental e médio; avaliação de situações de ensino-aprendizagem; elaboração de projeto de ensino, planos de ensino e de aula para os ensinos fundamental e médio; elaboração e aplicação de material didático para ensino/aprendizagem de língua inglesa para os ensinos fundamental e médio; avaliação de situações de ensino-aprendizagem; análise de material didático e de instrumentos avaliativos; gerenciamento e regência de sala de aula; observação e análise da realidade educacional da comunidade; uso da tecnologia no ensino; pesquisa-ação. 


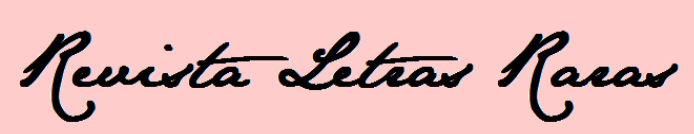

ISSN: 2317-2347 - v.6, n.1 (2017)

Por fim, o Estágio III, ofertado no oitavo período e para o nível de escolha do aluno licenciando, prevê: estudo do Projeto Político Pedagógico da comunidade escolar onde os alunos estiverem inseridos; elaboração de planos de ensino, de aula e material didático para ensino/aprendizagem de língua inglesa no ensino fundamental ou médio e sua aplicação na regência; e avaliação de situações de ensino-aprendizagem.

Percebe-se que as disciplinas mesclam questões conceituais e práticas que privilegiam um estudo crítico-reflexivo a partir da leitura dirigida de textos e documentos que embasam e norteiam a prática e o ensino das línguas estrangeiras modernas no Brasil e no Paraná.

Há que se ponderar, entretanto, que esse processo formativo parece não estar articulado com a internacionalização pelo fato de priorizar reflexões voltadas para a educação básica. O processo precisaria passar, assim, por adequações para oferecer uma formação atualizada frente às novas exigências da sociedade globalizada, de modo a ampliar a formação dos educandos e colaborar para a internacionalização do ensino superior, fortalecendo a instituição, a economia e a nação.

\section{A formação do professor de Língua Inglesa no Programa ISF}

Com a reformulação promovida pela Portaria no 973/2014, o Programa IsF, ao introduzir em seu discurso oficial a formação do professor, tornou-se um ambiente propício para o desenvolvimento do professor de língua inglesa sob a perspectiva da internacionalização (RAMOS et al., 2016; BRASIL, 2016; SARMENTO; KIRSCH, 2015; BRASIL, 2014).

Prioriza-se, no Programa, a contratação de professores-bolsistas licenciandos em Letras para que eles possam melhorar seu nível linguístico e seu conhecimento sobre a internacionalização (BRASIL, 2016; INTRODUÇÃO..., 2015). A eles são atribuídas as seguintes responsabilidades: desenvolver materiais didáticos e/ou atividades complementares de ensino de língua inglesa nas modalidades presencial e a distância; ministrar cursos presenciais; participar de reuniões acadêmicas e administrativas de planejamento e de estudos com o objetivo de garantir o bom andamento do NucLi, Núcleo de Línguas para o Programa IsF responsável por desenvolver e ofertar cursos de inglês e outras atividades linguísticopedagógicas na instituição credenciada (BRASIL, 2016; BRASIL, 2013). 


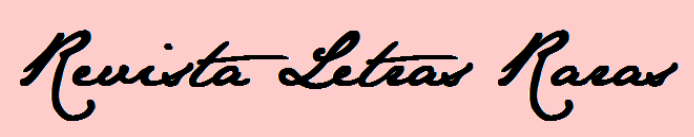

ISSN: 2317-2347 - v.6, n.1 (2017)

Como forma de valorização da carreira docente e da formação voltada para a internacionalização, são asseguradas aos professores bolsas remuneradas regulamentadas pela Coordenação de Aperfeiçoamento de Pessoal de Nível Superior (Capes). A contrapartida para o seu recebimento é a dedicação de 20 horas semanais ao Programa (BRASIL, 2016; PRINCÍPIOS..., 2016; ISF, 2016; INTRODUÇÃO..., 2015).

O IsF prevê a oferta de cursos não sequenciais voltados para habilidades ou temas específicos com forte foco na interação entre os participantes para oferecer à comunidade acadêmica o suporte linguístico necessário para que tomem parte no processo de internacionalização com muito mais facilidade. Orienta-se, assim, que eles sejam elaborados a partir da abordagem comunicativa, cujo foco é o uso efetivo da língua em situações reais de interação social (PRINCÍPIOS..., 2016; PARANÁ, 2008; SILVEIRA, 1999).

O cenário traçado justifica, portanto, a elaboração de aulas de inglês para fins específicos, construídas a partir das necessidades e interesses reais ou futuros dos aprendizes em relação ao uso do inglês em contextos alvos. As aulas devem, pois, centrar-se no desenvolvimento das habilidades linguísticas em foco por meio de atividades apropriadas para o propósito específico, preparando-os para se comunicar efetivamente em contextos acadêmicos e/ou profissionais (VILAÇA, 2010; DUDLEY-EVANS; JOHN, 1998; HUTCHINSON; WATERS; 1987).

Tem-se, portanto, que diferentemente dos cursos de inglês para fins gerais, cujas aulas são elaboradas a partir de situações da vida cotidiana para o desenvolvimento das habilidades linguísticas (VILAÇA, 2010), as aulas com fins específicos priorizam situações que desenvolvam "habilidades e conhecimentos delimitados com base no levantamento das necessidades dos alunos" (VILAÇA, 2010, p. 6).

Os professores do IsF devem, então, planejar suas aulas e/ou atividades a partir dessa perspectiva, sempre levando em consideração a abordagem comunicativa, metodologias e temáticas que facilitem a internacionalização do seu público alvo, em consonância com os princípios pedagógicos e objetivos do Programa (PRINCÍPIOS..., 2016).

Depreende-se, portanto, que pelo fato de o IsF ter sido concebido, essencialmente, de forma a colaborar com as políticas públicas brasileiras voltadas para a internacionalização das IES, o processo formativo do professor por ele oportunizado articula-se, ao menos na teoria, com essa perspectiva.

Tendo em vista o fato de o processo formativo do professor de língua inglesa na UTFPR parecer não estar articulado com as políticas públicas voltadas para a 


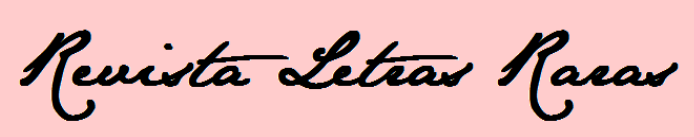

ISSN: 2317-2347 - v.6, n.1 (2017)

internacionalização da instituição, por priorizar uma formação voltada essencialmente para a educação básica, é possível inferir que o Programa IsF-Inglês da UTFPR tem potencial para preencher essa lacuna, complementando a formação docente dos professores-bolsistas acadêmicos do mesmo curso de maneira mais plena e substancial.

\section{Metodologia}

Com o intuito de se atingir os objetivos aqui traçados, a presente pesquisa, de natureza descritiva, adotou dois procedimentos para a coleta de dados.

Para verificar se o processo formativo oportunizado aos professores bolsistas do Programa IsF, acadêmicos do curso de Letras Português/Inglês da UTFPR, possibilita reforçar ou complementar os processos formativos desenvolvidos nos Estágios Curriculares Obrigatórios em Língua Inglesa I, II e III do curso no que diz respeito à internacionalização do ensino superior, o procedimento técnico foi a pesquisa bibliográfica e documental. Esse material também foi usado para a elaboração do questionário.

Para verificar, sob o ponto de vista dos discentes dos referidos Estágios, como os processos formativos nas disciplinas se relacionam com a questão da internacionalização do ensino superior, o procedimento técnico foi o levantamento quantitativo por meio de um questionário como instrumento de coleta de dados.

A escolha dessa licenciatura em particular se justifica pelo fato de a pesquisadora ter sido acadêmica do curso e professora bolsista do Programa IsF-Inglês na instituição. Já no que diz respeito aos discentes dos Estágios, a escolha foi motivada pelo fato de as disciplinas possibilitarem a eles a prática contextualizada das reflexões teóricas construídas ao longo do curso. Isso permitiu verificar como essa formação docente se relaciona com a questão da internacionalização do ensino superior, na prática, sob a ótica dos pesquisados.

Foram criados, então, três questionários iguais por meio do Google Formulários, os quais foram aplicados para cada subgrupo específico - discentes dos Estágios Curriculares Obrigatórios em Língua Inglesa I, II e III do curso.

Intitulado "A internacionalização no Estágio Curricular Obrigatório em Língua Inglesa", o questionário, composto por dez questões objetivas, fechadas e não obrigatórias, objetivou averiguar se os processos formativos do professor de língua inglesa nos Estágios 


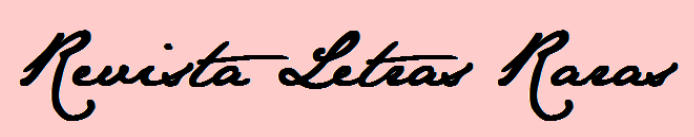

ISSN: 2317-2347 - v.6, n.1 (2017)

estavam articulados com as políticas públicas voltadas para a internacionalização do ensino superior a partir do ponto de vista dos acadêmicos regularmente matriculados no segundo semestre de 2016.

Em virtude do número reduzido da população pesquisada, o pré-teste do questionário foi aplicado a apenas um discente da Licenciatura que cursou os Estágios I e II e convalidou o Estágio III. Foi constatado que o questionário apresentava clareza, precisando apenas de pequenos ajustes. Por fim, apurou-se que a quantidade de perguntas foi adequada e que o pesquisado levou em torno de três minutos para respondê-lo.

As disciplinas de Estágio I e II contavam, cada uma, com 23 alunos matriculados. No Estágio III, por sua vez, havia 14 alunos inscritos, entretanto apenas 12 deles cursavam a disciplina de fato. A população total deste estudo foi, portanto, de 58 alunos.

Os questionários foram enviados por e-mail a todos eles e respondidos por 12 alunos do Estágio I, 12 do Estágio II e 12 do Estágio III, o que correspondeu a 62,07\% de toda a população pesquisada.

\section{Análise dos resultados}

A primeira pergunta, de múltipla escolha com possibilidade de apenas uma resposta, questionou qual foi o foco das leituras, atividades e discussões em sala sobre a prática docente na disciplina de Estágio Curricular Obrigatório em Língua Inglesa.

Os dados coletados confirmaram que as reflexões teóricas construídas nos três Estágios voltaram-se, essencialmente, para a educação básica, em consonância com o que os documentos oficiais que embasam o curso estabelecem, motivo pelo qual os Estágios não parecem se articular com a internacionalização.

É possível afirmar, portanto, que o processo formativo oportunizado aos professores bolsistas do IsF, acadêmicos do curso, ajudaria a preencher a lacuna percebida nos Estágios no que diz respeito à construção de reflexões teóricas voltadas para a internacionalização do ensino superior. Isso é justificado pelo fato de o IsF priorizar atividades que favoreçam o desenvolvimento de habilidades e competências do professor em formação para um ensino de língua voltado para a internacionalização.

Na segunda questão, de múltipla escolha e com possibilidade de seleção de apenas uma alternativa, os discentes responderam para qual público suas regências foram elaboradas 


\section{Reurita Letras Pacas}

ISSN: 2317-2347 - v.6, n.1 (2017)

e ministradas. O objetivo foi verificar se os públicos indicados nas ementas foram contemplados e se as regências estavam em harmonia com as reflexões teóricas.

Das 12 respostas coletadas junto ao Estágio I (Gráf.1), observou-se que a maior parte das regências concentrou-se no ensino médio, no ensino técnico e no CALEM, centro acadêmico da UTFPR que oferece cursos de línguas para alunos e servidores da instituição.

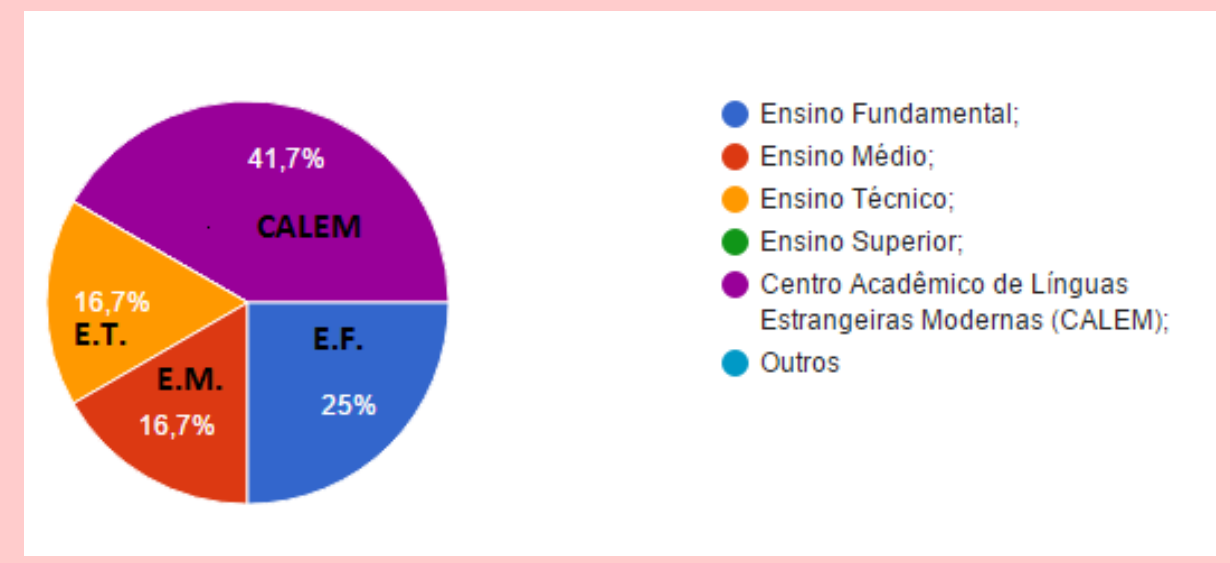

Gráf. 1 - Público das regências - discentes do Estágio I Fonte: Autoria própria

Infere-se, portanto, que as práticas não estão plenamente articuladas com as reflexões teóricas construídas durante as aulas, voltadas para a educação básica.

No Estágio II, que deveria privilegiar o ensino médio (UTFPR, 2011), metade dos pesquisados respondeu que as regências foram ministradas para o ensino fundamental e apenas $25 \%$ indicaram o ensino médio.

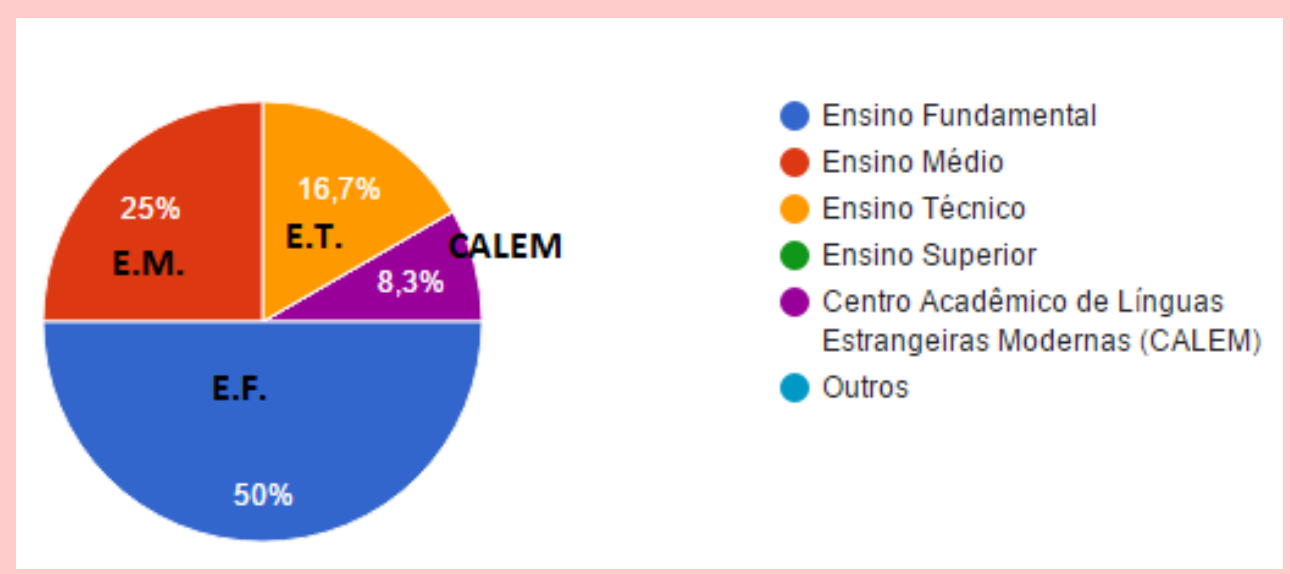

Gráf. 2 - Público das regências - discentes do Estágio II Fonte: Autoria própria

Depreende-se, portanto, que a situação delineada também não se alinha plenamente com a ementa ao não contar com a maioria dos discentes ministrando aulas para o público 


\section{Reuita atitas Tear}

ISSN: 2317-2347 - v.6, n.1 (2017)

indicado. Ressalta-se, contudo, que ainda que as regências não tenham sido ministradas em grande parte para o ensino médio, a prática voltada para a educação básica prevaleceu, em consonância com as orientações dos documentos que embasam suas atividades.

Por fim, segundo a ementa do Estágio III, os materiais didáticos preparados pelos discentes deveriam ser aplicados aos ensinos fundamental ou médio.

De acordo com as respostas (Gráf. 3), mais da metade dos pesquisados $(58,3 \%)$ desenvolveu e aplicou os materiais no ensino médio. Entretanto, o restante indicou outros públicos.

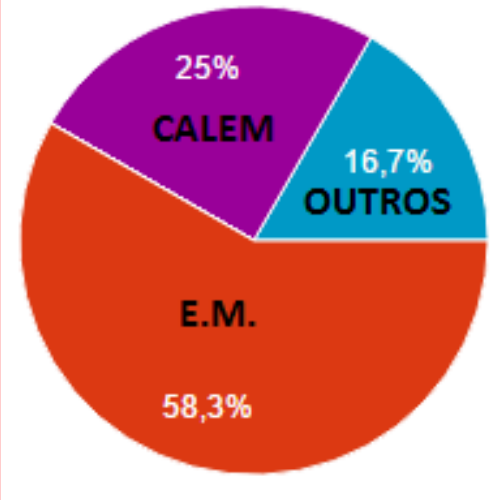

Ensino Fundamental

Ensino Médio

Ensino Técnico

Ensino Superior

Centro Acadêmico de Línguas Estrangeiras Modernas (CALEM)

Outros

Gráf. 3 - Público das regências - discentes do Estágio III Fonte: Autoria própria

O conjunto dos dados indica que as disciplinas priorizaram a educação básica como público das regências, conforme a orientação dos documentos que as guiam. Considerando que o público alvo das aulas de inglês com foco na internacionalização do ensino superior é a comunidade acadêmica das IES, percebe-se que as disciplinas não estão articuladas com as políticas públicas voltadas para a internacionalização do ensino superior.

Entende-se, assim, que o IsF ajudaria a complementar a formação oportunizada nos Estágios aos seus professores bolsistas acadêmicos de Letras pelo fato de trabalhar com um público distinto da educação básica.

A terceira questão, de múltipla escolha com possibilidade de seleção de mais de uma opção como resposta, verificou o principal método adotado pelos discentes para o planejamento e execução das regências de modo a confirmar se a abordagem comunicativa, criticada pelos documentos que amparam essa formação, foi adotada ou não.

Das 11 respostas coletadas no Estágio I, 90,9\% indicaram o método comunicativo e 9,1\% o método áudio-lingual. No Estágio II, das 12 respostas, 83,3\% indicaram o método 


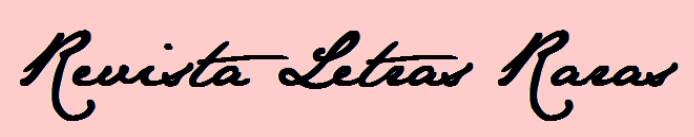

ISSN: 2317-2347 - v.6, n.1 (2017)

comunicativo e $41,7 \%$ o método tradicional. Finalmente, das 12 respostas dadas no Estágio III, $66,7 \%$ adotaram o método comunicativo, $25 \%$ o método tradicional e $8,3 \%$ o método áudio-lingual. Por fim, 16,7\%, ao selecionarem a opção "outros", revelaram usar outras abordagens pedagógicas de ensino de língua inglesa.

A partir desses dados, é possível perceber que a metodologia comunicativa foi a majoritariamente adotada pelos discentes nos estágios. Isso indica que, na prática, as disciplinas possivelmente privilegiaram essa metodologia e não se alinharam ao disposto nos documentos oficiais que embasam a formação docente na UTFPR, que não estimulam o desenvolvimento das habilidades comunicativas.

Os cursos do IsF, por sua vez, orientam que as aulas sejam elaboradas a partir do método comunicativo, de modo a oferecer à comunidade acadêmica o suporte linguístico necessário para que tomem parte no processo de internacionalização com facilidade.

Observa-se, assim, com relação à metodologia adotada para o planejamento e execução das regências, que os processos formativos nos três estágios estão em harmonia com a questão da internacionalização do ensino superior e que o Programa IsF reforçaria a formação preconizada em Letras, na prática, a seus professores bolsistas.

A quarta questão, de múltipla escolha com possibilidade de seleção de mais de uma opção, verificou quais foram as habilidades linguísticas trabalhadas nas regências ministradas pelos discentes dos Estágios I, II e III de modo a apurar se eles foram ou não além daquilo indicado nos documentos discutidos em sala.

A partir das 12 respostas coletadas no Estágio I, a habilidade mais trabalhada foi a compreensão oral $(91,7 \%)$, seguida pela produção oral e leitura $(83,3 \%$ cada). A menos trabalhada foi a escrita, indicada por $75 \%$ dos respondentes.

Similarmente, a compreensão oral foi também a mais trabalhada pelos discentes do Estágio II $(91,7 \%)$, seguida pela produção oral $(83,3 \%)$, leitura $(75 \%)$ e, por último, pela habilidade escrita $(66,7 \%)$.

No Estágio III, diferentemente das situações anteriores, extraiu-se, das 12 respostas obtidas, que a habilidade linguística mais trabalhada foi a escrita, foco de $100 \%$ dos discentes. As demais habilidades - leitura, produção oral e compreensão oral - vieram logo em seguida, empatadas com $91,7 \%$ cada.

Os dados revelam que as reflexões teóricas construídas durante as aulas nos três Estágios oportunizaram o desenvolvimento das competências e habilidades necessárias para que os discentes pudessem elaborar regências trabalhando as quatro habilidades linguísticas, 


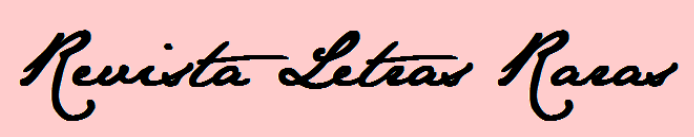

ISSN: 2317-2347 - v.6, n.1 (2017)

especialmente a compreensão oral, silenciada nos documentos que embasam essa formação. Isso indica que a licenciatura tem autonomia para escolher as habilidades mais relevantes a serem trabalhadas e que a formação vai além das orientações apresentadas nos documentos oficiais, articulando-se com a questão da internacionalização do ensino superior.

O processo formativo oportunizado ao professor bolsista do IsF, acadêmico de Letras da UTFPR, mais uma vez reforçaria a formação desenvolvida na licenciatura uma vez que os cursos presenciais do IsF trabalham com o desenvolvimento das quatro habilidades linguísticas com o objetivo de preparar seu público alvo para o processo de internacionalização.

Partindo do disposto nos documentos oficiais, que orientam o planejamento de aulas de língua inglesa a partir de temas, a quinta questão, de múltipla escolha com a possibilidade de seleção de apenas uma alternativa, conferiu qual foi a temática básica a partir da qual as regências ministradas pelos discentes dos três Estágios foram planejadas. O objetivo foi entender se a internacionalização é ou poderia ser uma questão trabalhada nas disciplinas.

No Estágio I, 83,3\% responderam que elas foram planejadas a partir de situações cotidianas. Nos Estágios II e III, todos os discentes responderam que elas foram desenvolvidas a partir de situações cotidianas. Infere-se, assim, que não há uma articulação dos Estágios com a internacionalização. O processo formativo oportunizado ao professor bolsista do Programa IsF, acadêmico de Letras, complementaria essa formação por priorizar o desenvolvimento de práticas voltadas para o trabalho com temáticas específicas relacionadas ao processo de internacionalização, com enfoque nas interações em contextos acadêmicos e/ou profissionais.

A sexta questão, de múltipla escolha com possibilidade de seleção de mais de uma opção, investigou os principais objetivos do ensino de língua inglesa discutidos nos três Estágios.

De acordo com os documentos que embasam o curso de Letras Português/Inglês da UTFPR, os principais objetivos do ensino de língua inglesa são: formar cidadão crítico; lutar contra a hegemonia e a favor da diversidade, construindo discursos alternativos; e desenvolver consciência crítica sobre o papel das línguas na sociedade.

No que diz respeito ao Programa IsF, são objetivos: contribuir para a internacionalização das IES; ampliar a participação em programas de intercâmbio; facilitar a produção e o intercâmbio científico e tecnológico; e proporcionar novas experiências 


\section{Reuita atitas Tear}

ISSN: 2317-2347 - v.6, n.1 (2017)

educacionais e profissionais voltadas para a qualidade, o empreendedorismo, a competitividade e a inovação.

Por fim, o objetivo comum a ambos é: aproximar o aluno de outras culturas e integrá-lo à sociedade globalizada, transformando a realidade social, econômica e política.

No Gráf. 4, nota-se que o item 4 foi escolhido como o principal objetivo do ensino de língua inglesa por $100 \%$ dos discentes do Estágio I. Esse objetivo, comum aos dois contextos formativos, foi seguido por objetivos contemplados especificamente pelo curso em análise: $66,7 \%$ selecionaram o item $3 ; 58,3 \%$ selecionaram o item 1 ; e 41,7\% selecionaram o item 2.

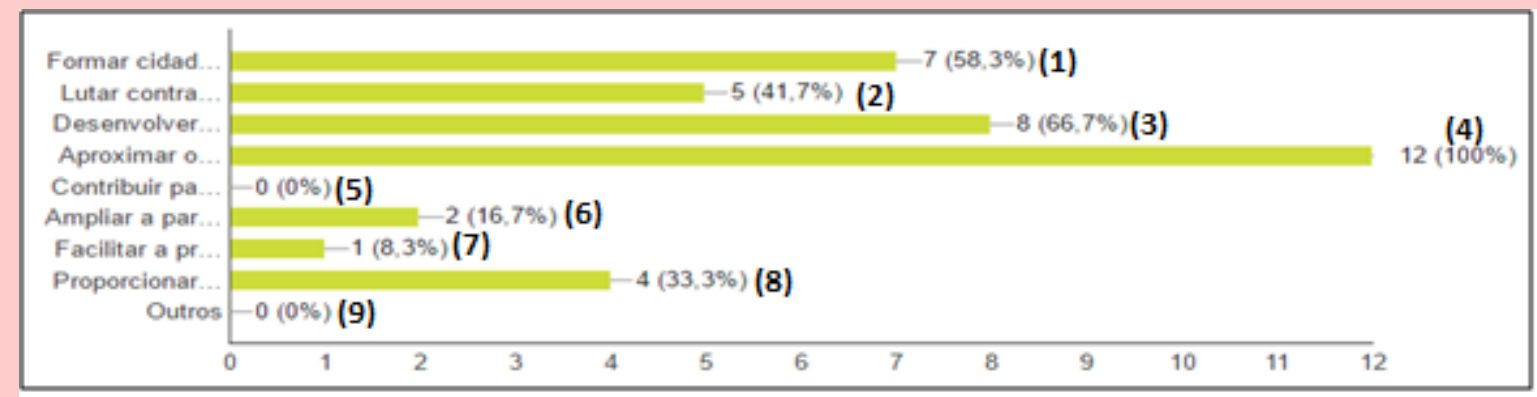

Gráf. 4 - Objetivos do ensino de inglês - discentes do Estágio I Fonte: Autoria própria

Os discentes também indicaram como objetivos discutidos no Estágio I aspectos não contemplados nos documentos que o embasam, mas que se configuram como objetivos do IsF, os itens 6,7 e 8.

A mesma dinâmica foi observada no Estágio II, conforme se verifica no Gráf. 5. Novamente, o objetivo apresentado no item 4 predominou em relação aos demais $(83,3 \%)$, seguido do item $3(75 \%)$, do item $1(58,3 \%)$ e do item $2(41,7 \%)$.

Dentre os objetivos do ensino de inglês privilegiados somente pelo IsF, mais uma vez o item 8 foi selecionado por 33,3\% dos pesquisados. A novidade fica por conta do item 5, apontado por $8,3 \%$ dos investigados.

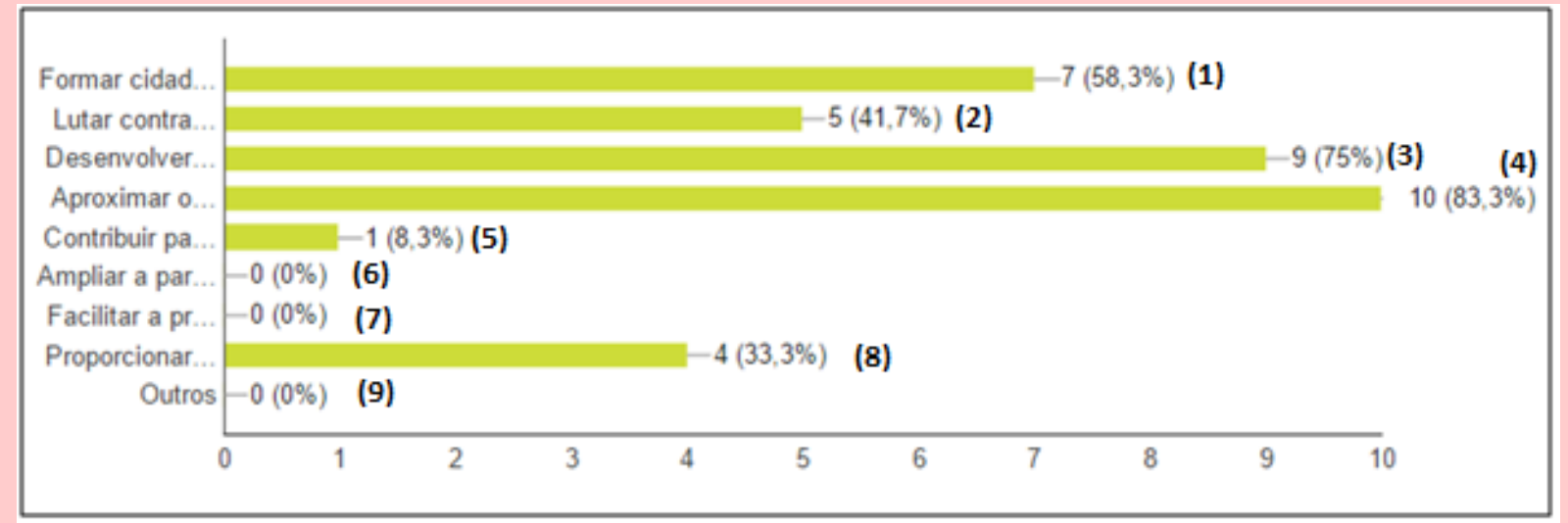




\section{Remitaditian Rear}

ISSN: 2317-2347 - v.6, n.1 (2017)

\section{Gráf. 5 - Objetivos do ensino de inglês - discentes do Estágio II Fonte: Autoria própria}

Por fim, o Estágio III seguiu a mesma tendência observada nos Estágios I e II. O item 4 foi destacado mais uma vez por $81,8 \%$ dos respondentes, o item 1 por $63,6 \%$, e os itens 2 e 4 por $54,5 \%$, respectivamente. O Gráf. 6 mostra, também, que os itens 7 e 8 foram selecionados por $18,2 \%$ e $27,3 \%$ respondentes, respectivamente.

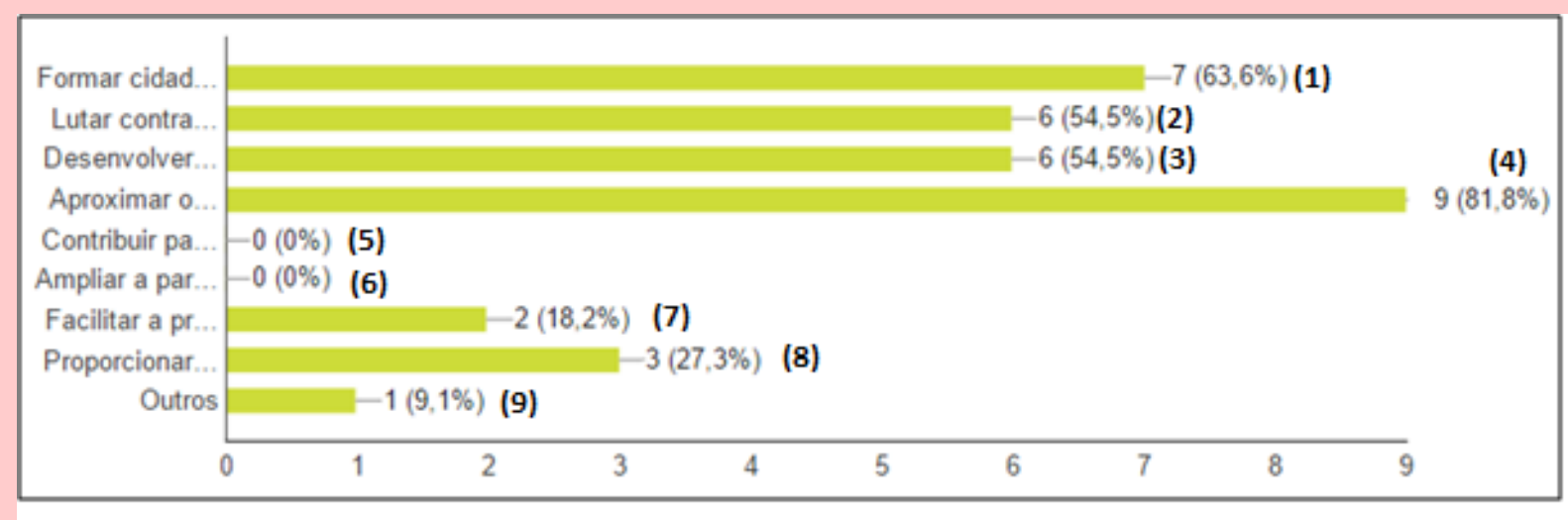

Gráf. 6 - Objetivos do ensino de inglês - discentes do Estágio III

Fonte: Autoria própria

Observa-se, a partir dos dados, que a maioria dos discentes indicou o item 4 como objetivo principal. Sendo esse um item comum aos dois processos formativos, infere-se que as duas realidades não estão tão distantes quanto parecem estar e que há espaço para um estreitamento das relações, fortalecendo tanto a licenciatura quanto a política linguística que sustenta o IsF.

Outro aspecto relevante é que os objetivos do ensino de língua inglesa discutidos nas disciplinas não se restringem àqueles que embasam essa formação. Eles vão além e abrangem, também, objetivos específicos do IsF, ainda que em menor proporção. Isso indica que os Estágios não se coadunam plenamente às orientações oficiais no âmbito da licenciatura em foco, mas que se harmonizam, relativamente, com a internacionalização.

A sétima questão verificou se os discentes receberam alguma instrução e/ou treinamento sobre como planejar e/ou lecionar aulas de inglês para fins específicos e/ou acadêmicos, aspecto privilegiado pelo IsF.

No Estágio I, das 12 respostas coletadas, 50\% responderam não e 41,7\% responderam sim. 


\section{Peuista Letraw Parar}

ISSN: 2317-2347 - v.6, n.1 (2017)

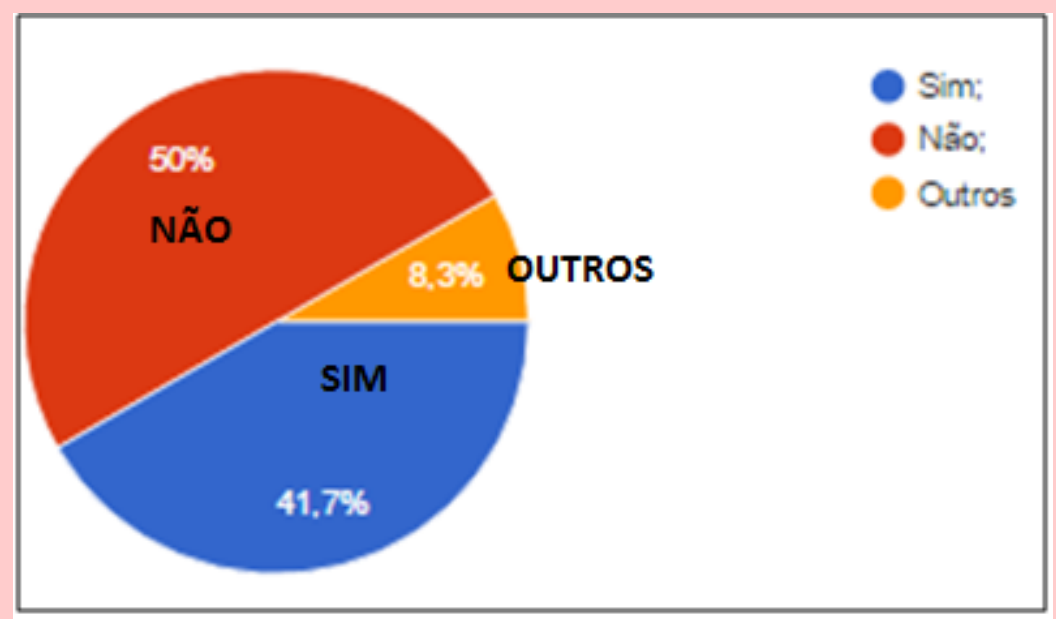

Gráf. 7 - Instrução ESP/EAP - discentes Estágio I Fonte: Autoria própria

Já no Estágio II, 66,7\% responderam que não receberam qualquer instrução e/ou treinamento e $33,3 \%$ responderam que sim.

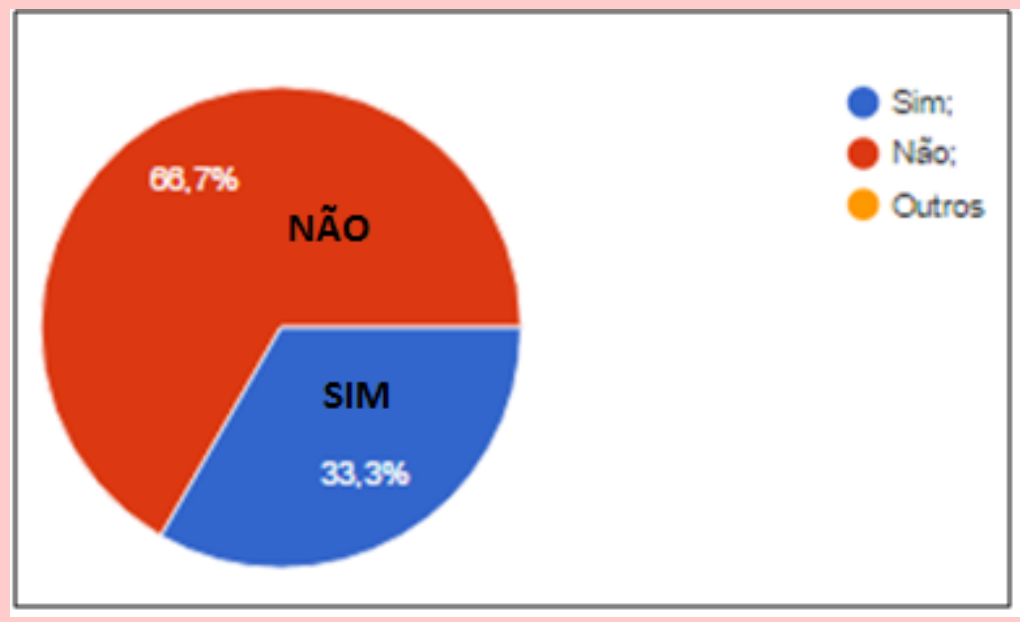

Gráf. 8 - Instrução ESP/EAP - discentes Estágio II Fonte: Autoria própria

Por fim, 66,7\% dos discentes do Estágio III responderam sim, 25\% responderam não, e $8,3 \%$ responderam que receberam parcialmente. 


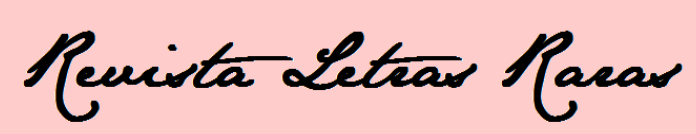

ISSN: 2317-2347 - v.6, n.1 (2017)

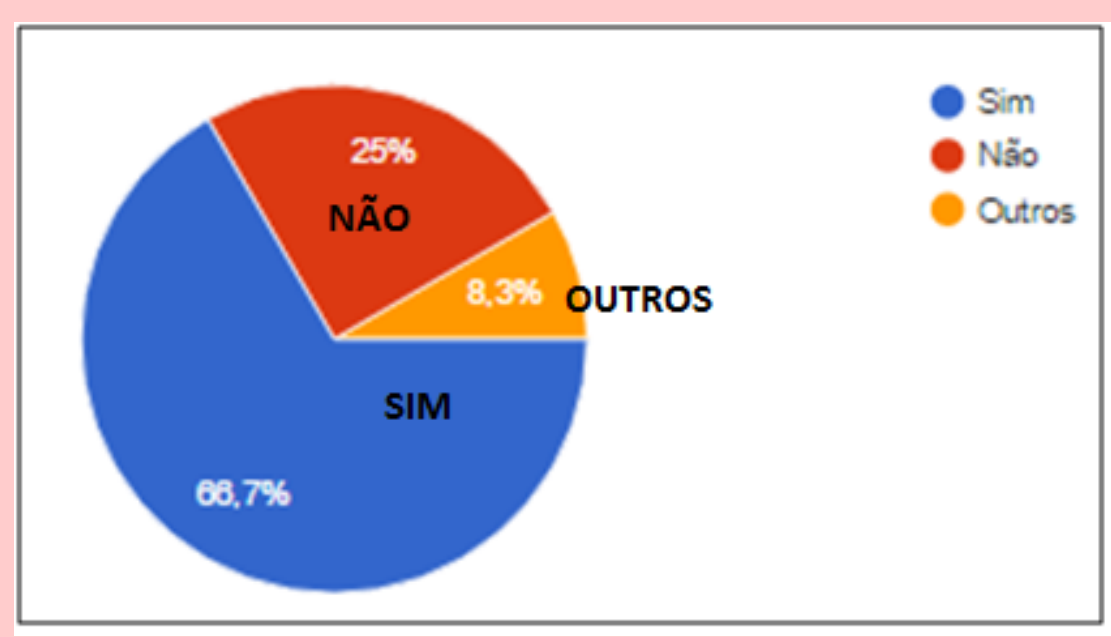

Gráf. 9 - Instrução ESP/EAP - discentes Estágio III Fonte: Autoria própria

De maneira geral, as informações obtidas são bastante contraditórias, especialmente nos Estágios I e II. Ainda que 50\% dos pesquisados do Estágio I e 66,7\% do Estágio II tenham respondido que não foram instruídos, uma parcela significativa respondeu que foi. Já no Estágio III o quadro se inverteu e mais da metade dos investigados respondeu que foram instruídos para isso.

Sabe-se que o ensino de língua proposto nos documentos que embasam a licenciatura em análise é aquele que não estimula o ensino de inglês para fins específicos, o que indica que, teoricamente, os Estágios não estariam articulados com a internacionalização. Isso não impossibilitou, entretanto, que esse aspecto fosse trabalhado nas disciplinas.

Essa possível abertura para outras reflexões, observada mais especificamente no Estágio III, sinaliza que essa formação possivelmente tenta desenvolver outras competências e habilidades que não somente aquelas voltadas para a educação básica.

Considerando que o IsF é, por excelência, um Programa que foi criado para fins específicos e também considerando que a iniciativa observada nos Estágios é ainda muito tímida, entende-se que o processo formativo do professor bolsista do IsF, acadêmico de Letras da UTFPR, mais uma vez complementaria a formação desenvolvida nos Estágios.

A oitava questão verificou se os discentes sabem o que é a internacionalização do ensino superior.

Nos Estágios I e II, 75\% de cada uma das populações responderam que não, entendimento compartilhado por $100 \%$ da população do Estágio III. Por outro lado, $25 \%$ dos respondentes de cada um dos Estágios I e II revelaram saber o que é a internacionalização. 


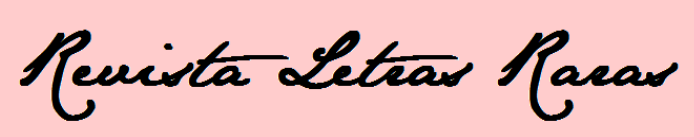

ISSN: 2317-2347 - v.6, n.1 (2017)

Constata-se, portanto, que a maioria dos discentes não sabe o que é a internacionalização do ensino superior.

A nona questão averiguou se durante as aulas dos Estágios I, II e III houve alguma reflexão e/ou instrução para o planejamento de aulas voltadas para a internacionalização do ensino superior.

Nos Estágios I e III, 100\% de ambos os grupos revelaram não terem refletido e/ou recebido essa instrução. No Estágio II, esse percentual diminui um pouco, caindo para 91,7\%, contra $8,3 \%$ que responderam sim.

Os dados parecem indicar que um dos motivos para a maioria dos discentes não saber o que é a internacionalização do ensino superior seria o fato de não terem refletido e/ou recebido qualquer instrução para o planejamento de aulas voltadas para essa situação específica.

Finalmente, a questão dez apurou se os discentes acham que os conteúdos teóricos e práticos do curso de Letras em foco os preparam para atuar no contexto da internacionalização do ensino superior.

No Estágio I, 91\% responderam não. No Estágio II, 58,3\% responderam não e 16,7\% responderam sim. Por fim, no Estágio III, 66,7\% responderam não e 16,7\% responderam sim.

Muito embora a internacionalização do ensino superior seja concebida, na atualidade, como uma importante ferramenta de adaptação de governos e instituições frente às novas demandas globais, depreende-se, a partir dos resultados apresentados nas questões 8, 9 e 10, que ela não é uma questão trabalhada, ao menos segundo a perspectiva do público pesquisado, nos Estágios do curso de Letras da UTFPR.

Os dados revelam que parece não haver uma articulação, por parte do curso, com a política institucional de internacionalização da UTFPR. Essa afirmação justifica-se pela constatação de que se priorizam reflexões teóricas e práticas docentes voltadas, em sua essência, para a educação básica, e não para outros contextos educacionais e/ou profissionais.

\section{Conclusão}

Esta pesquisa objetivou analisar a questão dos processos formativos do professor de língua inglesa desenvolvidos na Licenciatura em Letras Português/Inglês da UTFPR, câmpus Curitiba, e no Programa IsF com relação à internacionalização do ensino superior. 


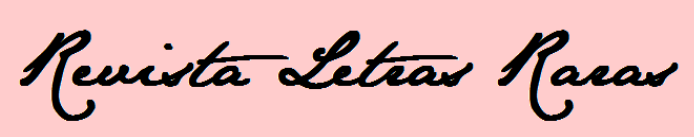

ISSN: 2317-2347 - v.6, n.1 (2017)

Para tanto, foram descritos, brevemente, os processos formativos priorizados no Brasil e no Paraná, bem como no referido curso e no IsF face aos novos desafios e dinâmicas impostos pelas sociedades contemporâneas globalizadas.

A pesquisa, de natureza descritiva, verificou, com um levantamento quantitativo por meio de um questionário como instrumento de coleta de dados, como os processos formativos do professor de língua inglesa nos Estágios Curriculares Obrigatórios em Língua Inglesa I, II e III da licenciatura se relacionam, na prática, com a internacionalização do ensino superior sob a ótica dos envolvidos.

Verificou, também, por meio de pesquisa bibliográfica e documental, se o processo formativo oportunizado aos professores bolsistas do IsF, acadêmicos do curso de Letras da UTFPR, possibilitaria reforçar ou complementar a formação desenvolvida nos Estágios do curso em foco no que diz respeito à internacionalização do ensino superior.

Como resultado, verificou-se que a formação nos Estágios não se articula, sob a perspectiva dos pesquisados, com a internacionalização do ensino superior, confirmando a inferência preliminar tecida a partir dos documentos analisados de que as disciplinas priorizam essencialmente práticas docentes voltadas para a educação básica.

Verificou-se, também, que o IsF, por promover a internacionalização do ensino superior em sua essência, tem potencial para preencher as lacunas observadas na formação do professor de língua inglesa na UTFPR. Complementaria, portanto, a formação dos professores bolsistas que fossem, também, acadêmicos do curso, de maneira mais plena e substancial.

Defende-se, assim, que as disciplinas de estágio precisariam passar por ajustes de modo a proporcionar ao futuro professor as ferramentas necessárias para prepará-lo para a realidade globalizada. Isso colaboraria para o seu desenvolvimento pessoal e profissional, e para o fortalecimento das IES, da economia e da sociedade como um todo, reforçando a relevância e o papel da nação diante do mundo globalizado.

Entende-se, por fim, que o Estágio III seria o contexto mais adequado para o desenvolvimento de práticas docentes voltadas para a internacionalização do ensino superior e que uma parceria com o NucLi/UTFPR poderia ser uma estratégia interessante e muito rica para complementar essa formação.

Essa iniciativa ajudaria a formar professores de língua inglesa mais bem preparados para as novas demandas das sociedades modernas e a fortalecer o Programa IsF na UTFPR, bem como o curso de Letras em relação à política de internacionalização da instituição. Por fim, promoveria a busca por respostas não só aos desafios da formação cidadã e dos 


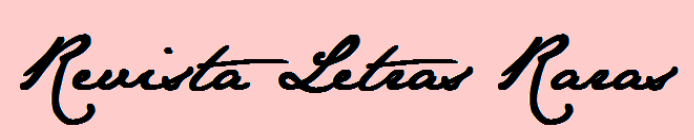

ISSN: 2317-2347 - v.6, n.1 (2017)

problemas da humanidade, mas também aos novos desafios da ciência, da tecnologia e da inovação, objetivos da política institucional da UTFPR.

\section{Referências}

ALTBACH, P. G. Globalization and the university: myths and realities in an unequal world. Tertiary Education And Management. Boston, p. 2-25. jan. 2010. Disponível em: <http://www.tandfonline.com/doi/abs/10.1080/13583883.2004.9967114>. Acesso em: 09 set. 2016.

ARCHANJO, R. Globalização e Multilinguismo no Brasil: competência linguística e o programa Ciência sem Fronteiras. Revista Brasileira de Linguística Aplicada, Belo Horizonte, v. 15, n. 3, p. 621-656, jul. 2015.

BATISTA, J. S. M. O processo de internacionalização das instituições de ensino superior: um estudo de caso na Universidade Federal de Uberlândia. Ribeirão Preto, 2009. 265 f.

Dissertação (Mestrado) - Curso de Administração de Organizações, Administração, Universidade de São Paulo.

BRASIL. Medida Provisória $n^{\circ}$ 746, de 22 de setembro de 2016. Diário Oficial da União. Ed. extra. Brasília, DF, 23 set. 2016. Seção 1, p. 1-2.

. Portaria no 30, de 26 de janeiro de 2016. Diário Oficial da União. 19. ed. Brasília, DF, 28 jan. 2016. Seção 1, p. 18-19.

. Portaria Normativa $\mathrm{n}^{\circ}$ 973, de 14 de novembro de 2014. Diário Oficial da União. 222. ed. Brasília, DF, 17 nov. 2014. Seção 1, p. 11-12.

Edital seleção de universidades federais para atuarem como centros aplicadores de exames de proficiência e como núcleos de línguas para o programa Inglês sem Fronteiras NucLi, de 10 de julho de 2013. Diário Oficial da União. 131. ed. Brasília, DF, 10 jul. 2013. Seção 1, p. 60.

. Portaria Normativa n ${ }^{\circ}$ 1.466, de 18 de janeiro de 2012. Diário Oficial da União. 244. ed. Brasília, DF, 19 jan. 2012. Seção 1, p. 28-29.

Decreto $\mathrm{n}^{\circ}$ 7.642, de 13 de dezembro de 2011. Diário Oficial da União. 239. ed. Brasília, DF, 14 dez. 2011. Secão 1, p. 7-8.

Ministério da Educação. Secretaria de Educação Básica. Orientações Curriculares para o Ensino Médio: linguagens, códigos e suas tecnologias. Brasília: Ministério da Educação, Secretaria da Educação Básica, 2006. 239 p.

. Resolução CNE/CP n ${ }^{\circ}$ 1, de 18 de fevereiro de 2002. Diário Oficial da União. 67. ed. Brasília, DF, 19 abr. 2002. Seção 1, p. 31.

. Parecer CNE/CES no 492, de 04 de abril de 2001. Diário Oficial da União. 131. ed. Brasília, DF, 09 jul. 2011. Seção 1, p. 50.

Secretaria de Educação Fundamental. Parâmetros curriculares nacionais: terceiro e quarto ciclos do ensino fundamental: língua estrangeira. Brasília: MEC/SEF, 1998. 120 p. 


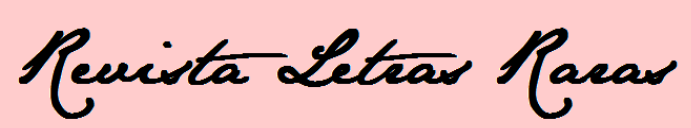

ISSN: 2317-2347 - v.6, n.1 (2017)

. Parecer do Conselho Nacional de Educação nº 776, de 03 de dezembro de 1997.

Orienta para as diretrizes curriculares dos cursos de graduação. Brasília, DF.

. Lei $\mathrm{n}^{\circ}$ 9.394, de 20 de dezembro de 1996. Diário Oficial da União. 248. ed. Brasília, DF, 23 dez. 1996. Seção 1. p. 27833.

CSF. O programa. 2016. Disponível em: <http://www.cienciasemfronteiras.gov.br/web/csf/oprograma>. Acesso em: 11 set. 2016.

DIAS SOBRINHO, J. Dilemas da Educação Superior no Mundo Globalizado: sociedade do conhecimento ou economia do conhecimento?. São Paulo: Casa do Psicólogo, 2005.

DUDLEY-EVANS, T.; JOHN, M. J. S. Developments in English for Specific Purposes: a multi-disciplinary approach. Cambridge: Cambridge University Press, 1998. 301 p.

ENGELMANN, P. C. M. O processo de formação docente na visão dos acadêmicos do curso de letras em uma universidade pública no estado do Paraná. Curitiba, 2012. 94 f. Dissertação (Mestrado) - Curso de Mediações e Culturas, Universidade Tecnológica Federal do Paraná.

GIMENEZ, T.; PASSONI, T. P. Políticas linguísticas e suas consequências não planejadas: o programa "Inglês Sem Fronteiras" e suas repercussões nos cursos de Letras. Calidoscópio, São Leopoldo, v. 14, n. 1, p. 115-126, jan. 2016.

HUTCHINSON, T.; WATERS, A. English for specific purposes: a learning-centred approach. Cambridge: Cambridge University Press, 1987. 183 p.

ISF. O programa. Disponível em: <http://isf.mec.gov.br/ingles/pt-br/o-programa>. Acesso em: 02 out. 2016.

INTRODUÇÃO ao Programa Idiomas sem Fronteiras. Intérpretes: Denise de Paula Martins de Abreu e Lima. [s.i]: Idiomas Sem Fronteiras, 2015. (22 min.), son., color.

KNIGHT, J. Higher Education in Turmoil: the changing world of internationalization.

Rotterdam/Taipei: Sense Publishers, 2008. Disponível em:

$<$ https://www.sensepublishers.com/media/475-higher-education-in-turmoil.pdf $>$. Acesso em: 10 set. 2016.

An Internationalization Model: Responding to New Realities and Challenges. In:

KNIGHT, J. et al (Org.). The higher education in Latin America: the international dimension. Washington, D.C.: The World Bank, 2005. p. 1-38. Disponível em:

<http://siteresources.worldbank.org/EXTLACREGTOPEDUCATION/Resources/Higher_Ed_ in_LAC_Intnal_Dimension.pdf>. Acesso em: 09 set. 2016.

LANGUAGES without Borders and the Internationalization of Brazilian Universities.

Intérpretes: Denise de Paula Martins de Abreu e Lima. Brasília: Idiomas Sem Fronteiras, 2016. (60 min.), son., color.

LAUS, S. P. A internacionalização da educação superior: um estudo de caso da Universidade Federal de Santa Catarina. Salvador, 2012. 331 f. Tese (Doutorado) - Escola de Administração, Universidade Federal da Bahia.

LIMA FILHO, D. L. Dimensões e limites da globalização. Petrópolis: Vozes, 2004.

LOPES, L. P. M. A nova ordem mundial, os Parâmetros Curriculares Nacionais e o ensino de inglês no Brasil: a base intelectual para uma ação política. In: BARBARA, L; RAMOS, R. C. 


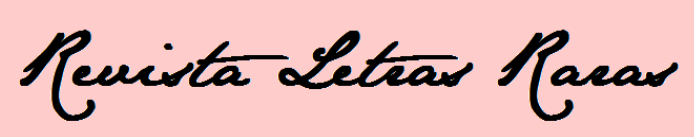

ISSN: 2317-2347 - v.6, n.1 (2017)

G. (Org.). Reflexões e ações no ensino-aprendizagem de línguas. Campinas: Mercado de Letras, 2003. p. 29-57.

MAGNOLI, D. Globalização: estado nacional e espaço mundial. 7. ed. São Paulo: Moderna, 1997.

MARRARA, T. Internacionalização da Pós-Graduação: objetivos, formas e avaliação. Revista Brasileira de Pós-graduação, Brasília, v. 4, n. 8, p. 245-262, dez. 2007.

OLIVEIRA, J. S. A Internacionalização da Educação Superior nas Relações Internacionais do Brasil: o caso do programa ciência sem fronteiras. Brasília, 2015. 32 f. Artigo

(Especialização) - Instituto de Relações Internacionais, Universidade de Brasília.

OTTO, S. I Encontro Internacional do Idiomas sem Fronteiras: internacionalização e multilinguismo na educação superior do brasil. Brasília: CESO, 2016. Disponível em: <http://isf.mec.gov.br/ingles/images/2016/agosto/Idiomas_sem_Fronteiras.pdf〉. Acesso em: 23 out. 2016.

PARANÁ. Secretaria de Estado da Educação. Diretrizes Curriculares da Educação Básica Língua Estrangeira Moderna. Curitiba: SEED PR, 2008.

PRINCÍPIOS pedagógicos do IsF. Intérprete: Denise de Paula Martins de Abreu e Lima. Brasília: Idiomas Sem Fronteiras Inglês, 2016. (44 min.), son., color.

RAMOS, Y. S. et al. Special Edition on the English without Borders Program. Belt - Brazilian English Language Teaching Journal, [s.1.], p. 1-3, 27 jan. 2016. EDIPUCRS. http://dx.doi.org/10.15448/2178-3640.2015.s.22951.

SARMENTO, S.; KIRSCH, W. Inglês Sem Fronteiras: uma mirada ao contexto de prática pelo prisma da formação de professores a partir do trabalho docente. Ilha do Desterro, Florianópolis, v. 68, n. 1, p. 47-69, jan. 2015.

SILVEIRA, M. I. M. Línguas estrangeiras: uma visão histórica das abordagens, métodos e técnicas de ensino. Maceió - São Paulo: Edições Catavento, 1999.

SOUZA, E. P. Mapeando os caminhos da internacionalização de instituições de ensino superior do Brasil. São Paulo, 2008. 233 f. Dissertação (Mestrado) - Curso de Administração, Universidade de São Paulo.

STALLAVIERI, L. Brazil's Science Without Borders Program. 2015. Disponível em: <https://www.insidehighered.com/blogs/world-view/brazils-science-without-bordersprogram>. Acesso em: 11 set. 2016.

TEODORO, A. A educação em tempos de globalização neoliberal. Brasília: Líber Livro, 2011.

UTFPR. $1^{\circ}$ Workshop de Internacionalização da UTFPR. Curitiba, 2014. Disponível em: $<$ http://www.utfpr.edu.br/estrutura-universitaria/diretorias-degestao/dircom/noticias/noticias/link/1o-workshop-de-internacionalizacao-da-utfpr>. Acesso em 03 out. 2016. 2011. . Projeto pedagógico do curso de licenciatura em letras português/inglês. Curitiba, . Projeto político-pedagógico institucional da UTFPR. Curitiba, 2007. 


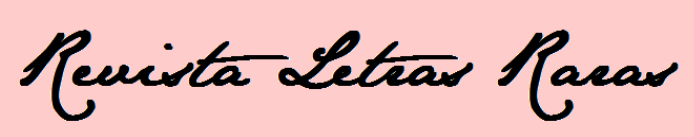

ISSN: 2317-2347 - v.6, n.1 (2017)

VILAÇA, M. L. C. English For Specific Purposes: fundamentos do ensino de inglês para fins específicos. Revista Eletrônica do Instituto de Humanidades, Rio de Janeiro, v. 9, n. 34, p. 1 12, out. 2010.

VOLPI, M.T. A formação de professores de língua estrangeira frente aos novos enfoques de sua função docente. In: LEFFA, V. J. O Professor de Línguas Estrangeiras: construindo a profissão. Pelotas: Educat, 2008. p. 133-141.

ZAMBONI, A. S. Q. A formação do professor de língua inglesa: um estudo interpretativo das ementas na formação inicial. Curitiba, 2013. 115 f. Dissertação (Mestrado em Letras), Universidade Federal do Paraná.

WENDE, M. D. Missing links: the relationship between national policies for internationalisation and those for higher education in general. In: KÄLVEMARK, T.;

WENDE, M. D. (Ed.). National Policies for the Internationalisation of Higher Education in Europe. Estocolmo: National Agency For Higher Education, 1997. p. 10-38. Disponível em: <http://www.uka.se/download/18.6f4a800151c42a802660ef/1454773992054/9708S.pdf>. Acesso em: 09 set. 2016.

WHITE, A. Melhoria Contínua da Qualidade. Rio de Janeiro: Record, 1998. 